\title{
ANALISA KEPUASAN MASYARAKAT DALAM KOMUNIKASI PARIWISATA TERHADAP WISATA DANAU TOBA BUKIT SIMARJARUNJUNG SIMALUNGUN
}

Irene Silviani ${ }^{1)}$, Nazlah Rachma Panggabean ${ }^{2)}$

1) Prodi Ilmu Komunikasi, Fakultas Ilmu Sosial dan Ilmu Politik, Universitas Darma Agung, E-mail: Irenesilviani@Gmail.Com

2) Prodi Akuntansi, Fakultas Ekonomi, Universitas Darma Agung, E-mail: Nazla89gabe@Gmail.Com

\section{ARTICLE INFORMATION}

KEYWORDS:

Satisfaction, Tourism Communication,

Simarjarunjung, Lake Toba

CORRESPONDENCE

Phone: 088262070305

E-mail: Irenesilviani@Gmail.Com

\begin{abstract}
A B $\quad S \quad T \quad R$ A $C$ C $T$
This study analyzed tourism communications related to community satisfaction in tourism services, quality of products, and the attraction of Lake Toba. Quantitative descriptive research using non probability and purposive sampling involving 100 respondents. The results showed that the majority of respondents were women as many as $58 \%$. While for men 42\%. Thus women are more likely to like Lake Toba tourism. Based on the simple linear regression equation, it is known that $Y=12.691+0.736 X$, which means that every $1 \%$ addition of the level of community satisfaction $(X)$ will increase Lake Toba tourism by +0.736 . While the comparison of the $t$ value and table, it is known that the $t$ value of 28.600 is greater than the table of 1.98447, so it is concluded that $\mathrm{HO}$ is rejected and $\mathrm{Ha}$ is accepted, that community satisfaction influenced on Lake Toba Tourism. The magnitude of the influence of community satisfaction on Lake Toba Tourism is obtained from the SPSS output with an $R$ Square value of 0.893. This means that the effect of community satisfaction on Lake Toba Tourism is $89.3 \%$, while $10.7 \%$ is influenced by variables are not in this study.
\end{abstract}

\section{INTRODUCTION}

Sejak periode 2015 sampai dengan 2018 terjadi penurunan yang signifikan atas wisatawan mancanegara dan wisatawan nusantara. Terjadi penurunan sebanyak 14\% dari tahun 2017 ke tahun 2018 (BPS.go.id). Tentu menjadi satu kehilangan yang cukup besar bagi pendapatan nasional juga bagi pendapat daerah bahkan bagi masyarakat setempat.

Penurunan ini kemungkinan disebabkan oleh ketidakpuasan wisatawan akan kualitas objek wisata yang dalam hal ini adalah kawasan wisata Danau Toba. Sangat disayangkan karena saat ini, daerah Danau Toba menjadi salah satu Destinasi Pariwisata Nasional dan Destinasi Pariwisata unggul di
Sumut. Belum lagi persoalan pandemic Covid19 yang mengakibatkan tidak bolehnya wisatawan asing datang ke Indonesia mengakibatkan semakin lemahnya sektor pariwisata saat ini. Untuk itu, peneliti ini ingin menganalisa mengenai kepuasan wisatawan terhadap pariwisata di kawasan Danau Toba.

Tujuan dari penelitian ini adalah :

1. Untuk menganalisis Komunikasi Pariwisata dalam Kualitas Pelayanan Pariwisata terhadap kepuasan wisatawan Kawasan Danau Toba

2. Untuk menganalisis Komunikasi Pariwisata dalam Kualitas Produk Wisata kepuasan Wisatawan Danau Toba. 
3. Untuk menganalisis Komunikasi Pariwisata dalam Kualitas Daya Tarik Wisata terhadap kepuasan wisatawan Kawasan Danau Toba.

Tingkat kepuasan seseorang berbedabeda satu dengan yang lain. Rasa puas dan tidak puas merupakan simpulan dari suatu pengalaman sebelum dan sesudah menggunakan sebuah produk atau mendapat pengalaman jasa dari orang lain. Penampilan yang tidak sesuai dengan yang diharapkan akan memberi rasa ketidakpuasan dan kekecewaan pada pelanggan dan jika sebanding maka pelanggan akan puas dan senang.

Kotler (2008) menjelaskan bahwa tingkat kepuasan seseorang berkaitan dengan kinerja atau hasil yang dibandingkan dengan harapannya. Rasa puas atau tidak puas adalah kesimpulan dari harapan serta pengalaman sebelum dan sesudah menggunakan suatu produk atau pengalaman jasa yang diberikan. Penampilan yang tidak sesuai dengan yang diharapkan akan memberi rasa ketidakpuasan dan kekecewaan pada pelanggan dan jika sebanding maka pelanggan akan puas dan senang.

Aris Baharuddin $\operatorname{dkk}(2016)$, menyatakan terdapat indikator untuk mengetahui kepuasan wisatawan terkait daya tarik wisata yaitu, pemandangan; akses/keterjangkauan; keamanan dan kenyamanan; fasilitas yang tersedia; infrastruktur jalan; serta pelayanan, dan informasi.

Smith dalam Kusumaningrum(2009) menjelaskan wisatawan sebagai orang yang sedang tidak bekerja, atau sedang berlibur dan secara sukarela mengunjungi daerah lain untuk mendapatkan sesuatu yang lain. Wisatawan yang berkunjung ke suatu daerah biasanya benar-benar ingin menghabiskan waktunya untuk bersantai, menyegarkan fikiran dan benar-benar ingin melepaskan diri dan rutinitas kehidupan sehari-hari. Dari pendapat di atas maka dapat dikatakan bahwa wisatawan adalah seseorang atau sekelompok orang yang sedang melakukan perjalanan ke tempat lain yang jauh dari rumah atau tempat asalnya untuk menjauh dari rutinitas rumah dan kantor.

Sedangkan menurut Hasan, (2015:4) wisatawan merupakan individu yang membuat perjalanan lebih dari satu hari satu malam untuk membeli pelayanan rekreasi dengan jarak tempuh minimal 25 mil. Wisatawan tersebut memiliki tujuan menggunakan sebagian besar waktunya untuk bersantai, meringankan pikiran dan ingin melepaskan diri dari ikatan kerja atau kehidupannya sehari-hari. Dari pendapat di atas maka dapat dikatakan bahwa wisatawan adalah seseorang atau sekelompok orang yang sedang melakukan perjalanan ke tempat lain yang jauh dari rumah atau tempat asalnya untuk menjauh dari rutinitas rumah dan kantor.

Hasan (2015:371-373) menyatakan bahwa faktor yang mempengaruhi kepuasan wisatawan itu seperti; keramahan masyarakat lokal; kualitas pelayanan yang menunjukkan kesopanan, keramahan, efisiensi dan sikap tanggap personel pelayanan pada permintaan dan keluhan wisatawan; akomodasi dan fasilitasnya secara fisik dan psikologis; budaya perilaku konsumsi produk wisata; harga yang bersaing dengan daerah lain; dan biaya non moneter dalam model persepsi nilai dan kualitas.

\section{METHOD}

Metode penelitian adalah deskriptif dengan pendekatan pengolahan data Kuantitatif. Hasil penelitian dianalisis dengan metode statistik (Sugiyono, 2014). Penelitian deskriptif ini juga bertujuan menguji hipotesis dan juga mendeskripsikan/mengidentifikasikan data yang dimaksudkan untuk mendapatkan gambaran mengenai kepuasan wisatawan terhadap perkembangan pariwisata Danau Toba. Lokasi Penelitian ini dilaksanakan di daerah Wisata Danau Toba di Bukit Simarjarunjung Simalungun, Sumatera Utara. Populasi adalah wisatawan yang berada di Simarjarunjung Danau Toba Kabupaten Simalungun. 
Metode pengambilan sampel ialah purposive dan Nonprobability Sampling. Hal ini dilakukan karena wisatawan yang diteliti tidak terduga, sehingga sebagai sumber data adalah orang yang sedang berkunjung ke Danau Toba Kabupaten Simalungun.

Teknik pengolahan data dengan cara membuat tabel, media koding dan editing, serta pemberian skor/nilai. Analisis Data melalui uji Validitas dan Reliabilitas Instrumen dimana diharapkan kuesioner sebagai alat yang digunakan adalah valid. Dalam penelitian validitas, dapat menggunakan SPSS (Stastistical Package for Social Science). Uji realibilitas dan uji validitas untuk menguji pertanyaan atau pernyataan. Setelah itu uji analisis regresi linear.

\section{RESULTS AND DISCUSSION}

\section{Deskripsi Bukit Indah Simarjarunjung}

Bukit Indah Simarjarunjung yang digunakan sebagai lokasi penyebaran angket untuk menganalisis kepuasan masyarakat terhadap wisata Danau Toba merupakan destinasi wisata yang terletak di desa Dolok Pardamean, Kabupaten Simalungun, Sumatera Utara. Jarak tempuh dari Medan adalah 123 $\mathrm{Km}$ dan lama perjalanan sekitar 4 jam melalui rute Medan - Berastagi - Kabanjahe - Saribu Dolok - Tiga Runggu - Dolok Pardamean.

Bukit Indah Simarjarunjung merupakan sebuah bukit yang dijadikan destinasi wisata karena pemandangannya yang indah, dan masih berada dikawasan Danau Toba. Bukit Indah Simarjarunjung dulu hanya sebuah bukit yang dijadikan sebagai tempat persinggahan atau rest area bagi wisatawan yang akan melakukan perjalanan ke Parapat. Potensi wisata Bukit Indah Simarjarunjung terdiri dari potensi wisata alam dan juga potensi wisata buatan manusia.

\section{Potensi Wisata Alam}

Bukit Indah Simarjarunjung memiliki potensi wisata alam yang indah. Panorama Danau Toba yang begitu indah yang banyak dikenal wisatawan, dapat dilihat langsung dari Bukit Indah Simarjarunjung. Potensi Wisata Buatan Manusia

Bukit Indah Simarjarunjung memiliki daya tarik karena penataan lokasinya menunjukkan ide-ide baru yang kreatif sehingga tidak hanya dijadikan tempat persinggahan tetapi telah dikelola dan dibangun agar wisatawan semakin tertarik untuk berkunjung dan menginap.

Pengembangan wisata di Bukit Indah Simarjarunjung dilengkapi dengan fasilitas umum seperti musholla, restoran, kantin, homestay, kios souvenir, parkir, dan toilet. Sehingga semua aktivitas wisatawan diharapkan dapat dilakukan dengan nyaman.

Berikut Foto Lokasi yang diabadikan peneliti. 


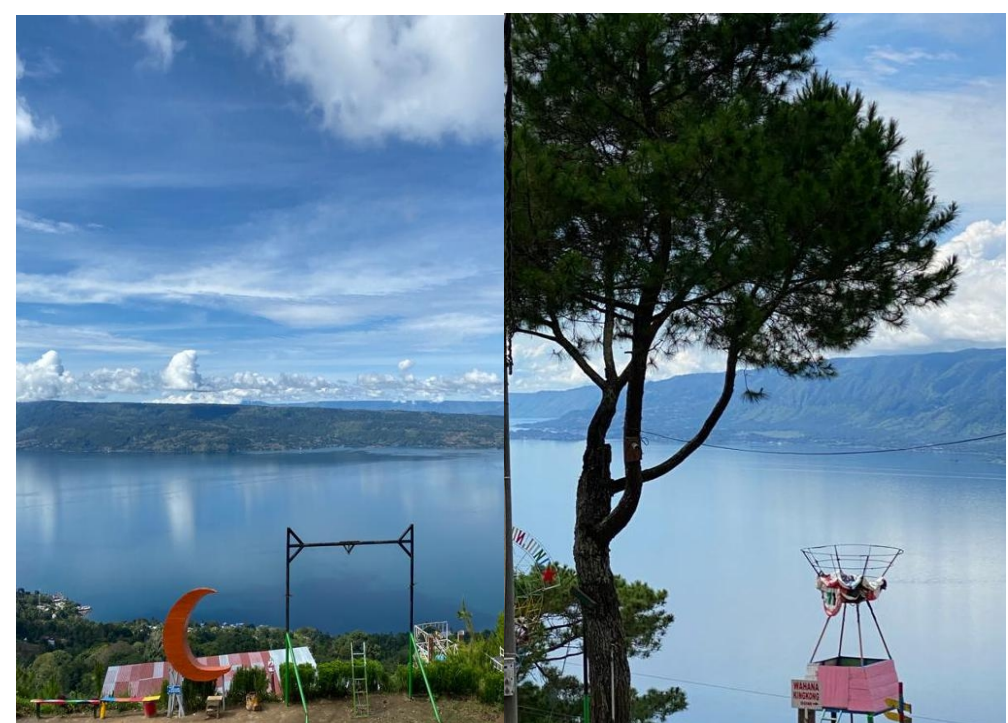

\section{Hasil Angket Responden}

Tabel1. di bawah ini adalah hasil jawaban responden terkait pertanyaan yang diberikan dalam angket.

Tabel 1.

Hasil Jawaban Responden di setiap Item Pertanyaan (Irene,2020)

\begin{tabular}{|c|c|c|c|c|c|c|c|c|c|}
\hline \multirow[t]{3}{*}{ No } & \multirow{3}{*}{$\begin{array}{l}\text { Pernyataan } \\
\text { Kepuasan Masyarakat (X) }\end{array}$} & \multicolumn{8}{|c|}{ Skala Likert Frekuensi } \\
\hline & & \multirow[t]{2}{*}{ SS } & & \multicolumn{2}{|c|}{ Setuju } & \multirow[t]{2}{*}{$\mathbf{K S}$} & \multicolumn{3}{|c|}{ TS } \\
\hline & & & $\%$ & & $\%$ & & $\%$ & & $\%$ \\
\hline 1 & $\begin{array}{lll}\text { Kualitas } & \text { Pelayanan } & \text { Sesuai } \\
\text { Standar } & & \end{array}$ & 3 & 3,0 & 63 & 63,0 & 34 & 34,0 & 0 & 0,0 \\
\hline 2 & $\begin{array}{l}\text { Informasi Menggunakan } \\
\text { Komunikasi Persuasif }\end{array}$ & 6 & 6,0 & 62 & 62,0 & 32 & 32,0 & 0 & 0,0 \\
\hline 3 & $\begin{array}{l}\text { Kredibilitas } \\
\text { Wisatawan }\end{array}$ & 4 & 4,0 & 69 & 69,0 & 27 & 27,0 & 0 & 0,0 \\
\hline 4 & $\begin{array}{l}\text { Keamanan Wisata Danau } \\
\text { Toba Terjamin }\end{array}$ & 0 & 0,0 & 53 & 53,0 & 47 & 47,0 & 0 & 0,0 \\
\hline 5 & $\begin{array}{l}\text { Pelayanan Memperhatikan } \\
\text { Kepuasan Pelanggan }\end{array}$ & 5 & 5,0 & 51 & 51,0 & 43 & 43,0 & 1 & 1,0 \\
\hline 6 & Kegiatan Wisata Menarik & 3 & 3,0 & 43 & 43,0 & 53 & 53,0 & 1 & 1,0 \\
\hline 7 & $\begin{array}{l}\text { Informasi destinasi ada di } \\
\text { Media Massa dan Media } \\
\text { Sosial }\end{array}$ & 23 & 23,0 & 66 & 66,0 & 11 & 11,0 & 0 & 0,0 \\
\hline 8 & $\begin{array}{l}\text { Fasilitas Umum Bersih dan } \\
\text { Nyaman }\end{array}$ & 0 & 0,0 & 25 & 25,0 & 71 & 71,0 & 4 & 4,0 \\
\hline 9 & $\begin{array}{l}\text { Pelayanan Wisata Danau } \\
\text { Toba memuaskan }\end{array}$ & 0 & 0,0 & 55 & 55,0 & 42 & 42,0 & 3 & 3,0 \\
\hline 10 & $\begin{array}{l}\text { Akses menuju lokasi mudah } \\
\text { dilalui }\end{array}$ & 0 & 0,0 & 75 & 75,0 & 25 & 25,0 & 0 & 0,0 \\
\hline 11 & $\begin{array}{l}\text { Ada keinginan berwisata } \\
\text { karena akses wisata mudah }\end{array}$ & 27 & 27,0 & 54 & 54,0 & 19 & 19,0 & 0 & 0,0 \\
\hline
\end{tabular}




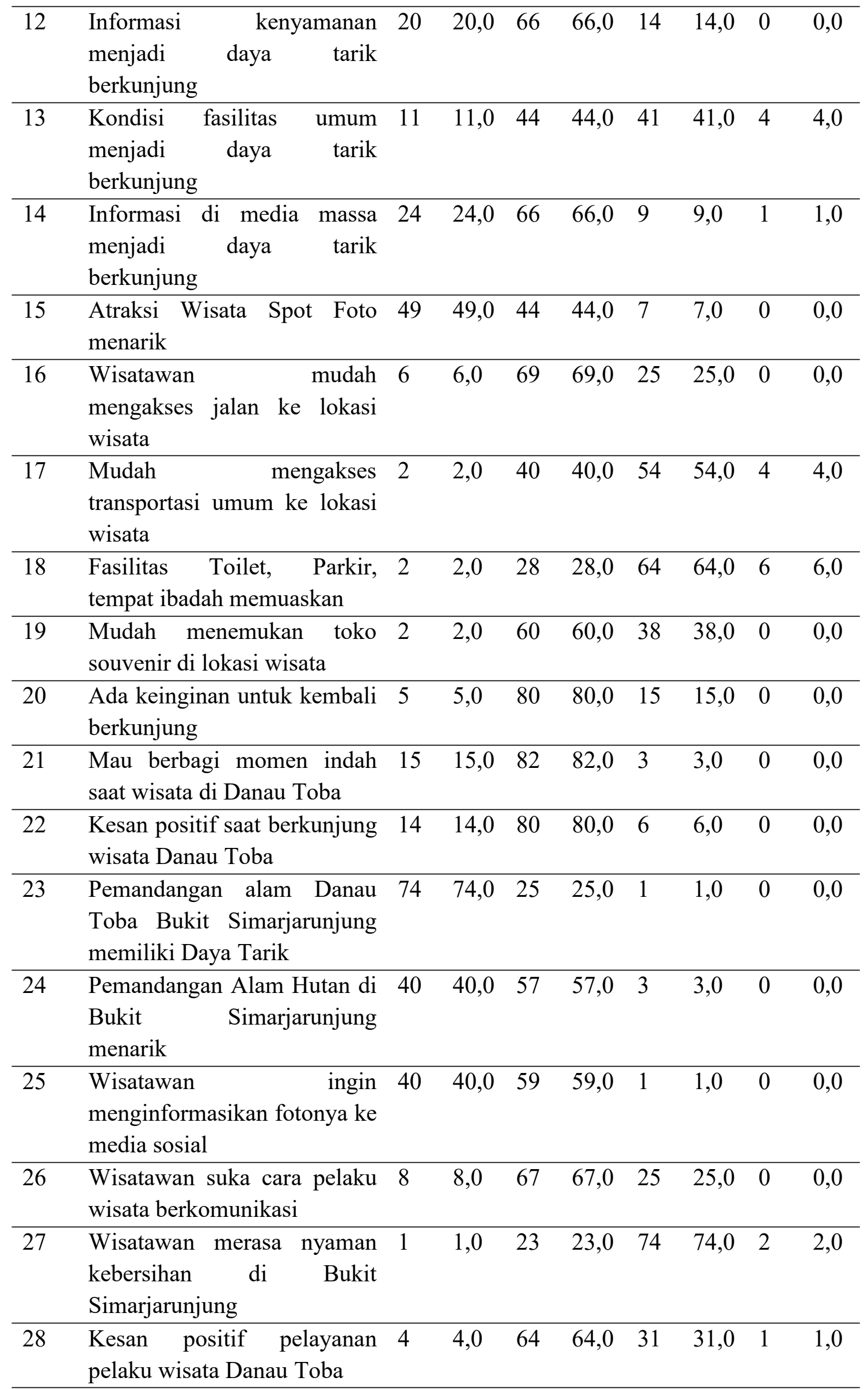


Berdasarkan data tabel 1, mayoritas responden sudah mengatakan bahwa kualitas pelayanan sesuai standar dengan informasi yang disampaikan sudah menggunakan komunikasi persuasive yaitu $62 \%$ atau 62 orang. Tetapi terkait keamanan di sekitar Danau Toba 47 orang mengatakan kurang setuju. Hampir 50\%.

Hal ini merupakan pesan penting agar pemerintah dapat memperhatikan kondisi ini sehingga ke depannya benar-benar dapat memberikan rasa aman yang menjadi nilai jual daya tarik orang ingin berwisata. Terkait fasilitas umum yang bersih, mayoritas responden mengatakan kurang setuju yaitu 71 orang. Ini jumlah yang banyak karena $2 / 3$ mayoritas responden mengeluhkan kebersihan di wisata Danau Toba.

Pemandangan Danau Toba yang indah tidak akan dapat dinikmati jika kondisi kebersihan masih menjadi masalah yang besar di destinasi Danau Toba. Berdasarkan data diatas, walaupun kondisi keamanan dan kebersihan meresahkan tetapi mereka masih ada niat untuk berkunjung dan mayoritas responden mengatakan bahwa infomasi dari media massa dan media sosial menjadi daya tarik utama bagi mereka untuk berkunjung.

Atraksi wisata dan spot foto di Bukit Indah Simarjarunjung menarik bagi responden yaitu 49\% sangat setuju dan setuju 44\%. Data ini menunjukkan 93\% responden memberikan apresiasi positif terkait wisata buatan yang digabungkan dengan latar pemandangan alam Danau Toba melalui spot Foto yang ada di Bukit Indah Simarjarunjung. Sedangkan Fasilitas Toilet, Parkir, tempat ibadah belum memuaskan dengan jawaban responden sebanyak 64\% kurang setuju dan 6\% tidak setuju. Ini membuktikan terdapat $70 \%$ responden belum puas akan fasilitas di Bukit indah Simarjarunjung. Namun mayoritas responden juga menyatakan mau berbagi kesan positif momen indah mereka pada orang lain yaitu sebanyak $82 \%$. Hal ini sesuai dengan pernyataan mereka bahwa atraksi dan spot foto menjadi daya tarik untuk datang berkunjung sehingga terdapat $40 \%$ sangat setuju membagi fotonya di media sosial dan, 59\% lagi setuju. Dalam hal ini 99\% respoden memang datang untuk menikmati foto di Bukit indah Simarjarunjung. Sedangkan kondisi kebersihan masih kurang nyaman bagi mereka dengan jawaban responden kurang setuju $74 \%$ dan tidak setuju 2\%. Hal ini menjadi tugas penting pemerintah Simalungun untuk memperbaikinya. Jika tidak diperbaiki dapat berdampak mereka bosan dan mencari yang lain yang lebih memberikan kenyamanan.

\section{Pengujian Validitas \& Reliabilitas Terhadap Item Kuesioner}

Pengujian ini digunakan untuk mengukur pertanyaan penelitian yang dijadikan alat mengukur tingkat kepuasan masyarakat dan wisata Danau Toba. Adapun penelitian ini menggunakan 28 item pertanyaan dari indikator $\mathrm{X}$ dan $\mathrm{Y}$. Berikut hasil pengujian tersebut berdasarkan SPSS 27.

\section{Validitas}

Suatu angket pertanyaan dianggap valid jika pertanyaan tersebut mampu menjelaskan sesuatu dari indikator yang digunakan dalam angket tersebut (Ghozali, 2011:52) Instrument dikatakan valid atau sahih jika validitasnya tinggi, sebaliknya pernyataan atau pertanyaan dalam angket kurang valid jika memiliki validitas rendah. Pengujian instrumen tersebut dengan menggunakan program SPSS 27 dengan signifikansinya sebesar $5 \% \quad(0,05)$. Pengujian instrument dengan 100 responden dapat dilihat di bawah ini, yaitu :

Tabel 2. 


\begin{tabular}{|c|c|c|c|c|}
\hline $\begin{array}{c}\text { Variabel } \\
\text { Penelitian }\end{array}$ & Item & r hitung & $\begin{array}{c}r \\
\text { tabel }\end{array}$ & $\begin{array}{c}\text { Keteranga } \\
\mathbf{n}\end{array}$ \\
\hline \multirow{28}{*}{$\begin{array}{l}\text { Kepuasan } \\
\text { Masyarakat } \\
\text { (X) }\end{array}$} & Kualitas Pelayanan Sesuai & 0.740 & 0,196 & Valid \\
\hline & Standar & & 6 & \\
\hline & Menggunakan & 0.774 & 0,196 & Valid \\
\hline & Persuasif & & 6 & \\
\hline & Kredibilitas Diakui Wisatawan & 0,716 & 0,196 & Valid \\
\hline & & & 6 & \\
\hline & Keamanan Wisata Danau Toba & 0,532 & 0,196 & Valid \\
\hline & Terjamin & & 6 & \\
\hline & Pelayanan $\quad$ Memperhatikan & 0,549 & 0,196 & Valid \\
\hline & Kepuasan Pelanggan & & 6 & \\
\hline & Kegiatan Wisata Menarik & 0,479 & 0,196 & Valid \\
\hline & & & 6 & \\
\hline & Informasi destinasi ada di & 0,586 & 0,196 & Valid \\
\hline & Media Massa dan Media Sosial & & 6 & \\
\hline & Fasilitas Umum Bersih dan & 0,466 & 0,196 & Valid \\
\hline & Nyaman & & 6 & \\
\hline & Pelayanan Wisata Danau Toba & 0,383 & 0,196 & Valid \\
\hline & memuaskan & & 6 & \\
\hline & Akses menuju lokasi mudah & 0,611 & 0,196 & Valid \\
\hline & dilalui & & 6 & \\
\hline & Ada keinginan berwisata & 0,598 & 0,196 & Valid \\
\hline & karena akses wisata mudah & & 6 & \\
\hline & Informasi kenyamanan menjadi & 0,631 & 0,196 & Valid \\
\hline & daya tarik berkunjung & & 6 & \\
\hline & Kondisi fasilitas umum menjadi & 0,715 & 0,196 & Valid \\
\hline & daya tarik berkunjung & & 6 & \\
\hline & Informasi di media massa & 0,540 & 0,196 & Valid \\
\hline & menjadi daya tarik berkunjung & & 6 & \\
\hline \multirow{15}{*}{$\begin{array}{l}\text { Wisata } \\
\text { Danau } \\
\text { Toba } \\
\text { (Y) }\end{array}$} & Atraksi Wisata Spot Foto & 0,438 & 0,196 & Valid \\
\hline & menarik & & 6 & \\
\hline & Wisatawan mudah mengakses & 0,661 & 0,196 & Valid \\
\hline & jalan ke lokasi wisata & & 6 & \\
\hline & Mudah mengakses transportasi & 0,602 & 0,196 & Valid \\
\hline & umum ke lokasi wisata & & 6 & \\
\hline & Fasilitas Toilet, Parkir, tempat & 0,541 & 0,196 & Valid \\
\hline & ibadah memuaskan & & 6 & \\
\hline & Mudah menemukan tokoh & 0,661 & 0,196 & Valid \\
\hline & souvenir di lokasi wisata & & 6 & \\
\hline & Ada keinginan untuk kembali & 0,531 & 0,196 & Valid \\
\hline & berkunjung & & 6 & \\
\hline & Mau berbagi kesan saat wisata & 0,344 & 0,196 & Valid \\
\hline & di Danau Toba & & 6 & \\
\hline & Kesan positif saat berkunjung & 0,408 & 0,196 & Valid \\
\hline
\end{tabular}




\begin{tabular}{|c|c|c|c|}
\hline wisata Danau Toba & & 6 & \\
\hline $\begin{array}{l}\text { Pemandangan Alam Bukit } \\
\text { Simarjarunjung memiliki daya } \\
\text { tarik }\end{array}$ & 0,328 & $\begin{array}{c}0,196 \\
6\end{array}$ & Valid \\
\hline $\begin{array}{l}\text { Pemandangan Hutan di Bukit } \\
\text { Sismarjarunjung menarik }\end{array}$ & 0,373 & $\begin{array}{c}0,196 \\
6\end{array}$ & Valid \\
\hline $\begin{array}{l}\text { Wisatawan } \\
\text { menginformasikan Fotonya ke } \\
\text { Media Sosial }\end{array}$ & 0,388 & $\begin{array}{c}0,196 \\
6\end{array}$ & Valid \\
\hline $\begin{array}{l}\text { Wisatawan menyukai informasi } \\
\text { di objek wisata }\end{array}$ & 0,448 & $\begin{array}{c}0,196 \\
6\end{array}$ & Valid \\
\hline $\begin{array}{lcr}\text { Wisatawan merasa } & \text { nyaman } \\
\text { kebersihan } & \text { di } & \text { Bukit } \\
\text { Simarjarunjung } & & \\
\end{array}$ & 0,473 & $\begin{array}{c}0,196 \\
6\end{array}$ & Valid \\
\hline $\begin{array}{l}\text { Kesan positif pelayanan pelaku } \\
\text { wisata Danau Toba }\end{array}$ & 0,807 & $\begin{array}{c}0,196 \\
6\end{array}$ & Valid \\
\hline
\end{tabular}

Berdasarkan tabel tersebut nilai rhitung $>$ (lebih besar dan positif) dibandingkan rtabel untuk $(\mathrm{df})=100-2=98$ dengansignifikansi 5\% yaitu sebesar 0,1966 maka, semua indikator dari variabelX dan $\mathrm{Y}$ dapat dikatakan valid.

\section{Reliabilitas}

Hasil uji yang dilakukan menggunakan nilai cronbach 'salpha $>0,60$ sesuai pernyataan Sujarweni (2014:193). Pengujian berdasarkan program SPSS 27, dapat dilihat di tabel ini.

Tabel 3.

Reliabilitas Variabel Kepuasan Masyarakat dan Wisata Toba

\begin{tabular}{llll}
\hline \multicolumn{4}{c}{ Reliability Statistics Variabel Kepuasan Masyarakat (X) dan Wisata (Y) } \\
\hline \multicolumn{2}{c}{ ReliabilityStatistics VariabelX } & \multicolumn{2}{c}{ ReliabilityStatistics VariabelY } \\
\hline C'Alpha & N of Items & C'Alpha & N of Items \\
\hline 0,857 & 14 & 0,773 & 14 \\
\hline
\end{tabular}

Berdasarkan tabel 3 diatas, Dengan demikian kuesioner atau angket pertanyaan dalam variabel Kepuasan Masyarakat (X) dan Wisata Danau Toba (Y) dinyatakan reliabel atau konsisten.

\section{Uji Normalitas}

Pengujian ini juga sebagai cara menganalisa data sebelum analisis statistik atau uji hipotesis (analisisregresi linear sederhana) dilakukan.

Tabel4.

UjiNormalitas

\begin{tabular}{lcccrrr}
\hline \multicolumn{4}{c}{ Normality Test } & \multicolumn{3}{c}{ Shap.-Wilk } \\
\cline { 2 - 7 } & Statistic & df & Sig. & Statistic & df & Sig. \\
\hline $\begin{array}{l}\text { Unstandardized } \\
\text { Residual }\end{array}$ & 0,085 & 100 & 0,075 & 0,980 & 100 & 0,124 \\
\hline
\end{tabular}


a. Lilliefors Significance Correction

Berdasarkan tes normalitas yang menggunakan SPSS 27, maka dapat dilihat bahwa, nilaisignifikansi uji normalitas Kolmogorov-Smirnova ${ }^{\text {, }}$, sebesar 0,075 > (lebih besar) dari 0,05. Dapat disimpulkan penelitian ini menggunakan data yang penyebarannya normal walaupun sangat kecil. Nilai signifikansi pada uji Shapiro-wilk juga lebih besar yaitu $0,124>0,05$ sehingga data juga sama.

\section{Linearitas}

Pengujian ini dilakukan untuk melihat apakah variabel yang digunakan mempunyai hubunganlinear atau tidak secara signifikan. Hal ini sebagai syarat melakukan analisis regresi linear.

Tabel 5.

Output ANOVA TableLinearitas

\begin{tabular}{|c|c|c|c|c|c|c|c|}
\hline \multicolumn{8}{|c|}{ ANOVA } \\
\hline & & & \multicolumn{2}{|l|}{ Sum of } & \multicolumn{3}{|l|}{ Mean } \\
\hline & & & Squares & df & Square & $\mathrm{F}$ & Sig. \\
\hline \multirow[t]{5}{*}{$\mathrm{Y} * \mathrm{X}$} & \multirow{3}{*}{$\begin{array}{l}\text { Between } \\
\text { Groups }\end{array}$} & (Combined) & 1243,606 & 21 & 59,219 & 45,204 & 0,000 \\
\hline & & Linearity & 1201,806 & 1 & 1201,806 & 917,372 & 0,000 \\
\hline & & $\begin{array}{l}\text { Deviation } \\
\text { from } \\
\text { Linearity }\end{array}$ & 41,800 & 20 & 2,090 & 1,595 & 0,075 \\
\hline & \multicolumn{2}{|c|}{ Within Groups } & 102,184 & 78 & 1,310 & & \\
\hline & \multicolumn{2}{|l|}{ Total } & 1345,790 & 99 & & & \\
\hline
\end{tabular}

Sumber : Data SPSS 27

Berdasarkan ANOVA Table diatas diketahui deviation from linearity Sig. adalah $0,075>$ (lebih besar) dari 0,05. Terdapat hubungan linear secara signifikan antara variabel Kepuasan masyarakat dengan wisata Danau Toba. Sedangkan cara membandingkan Regresi Linear Sederhana
nilaiF, diketahui bahwa Fhitung adalah 1,595< Ftabel 1,720. Hal ini menjelaskan kepada kita bahwa terdapat hubungan linear antara Kepuasan Masyarakat dengan Wisata Danau Toba.

Tabel. 6

Coefficients/ Hasil Regresi Linear Sederhana

\begin{tabular}{|c|c|c|c|c|c|}
\hline \multicolumn{6}{|c|}{ Coefficients $^{\mathrm{a}}$} \\
\hline \multirow[b]{2}{*}{ Model } & $\begin{array}{r}\text { Unstand } \\
\text { Coeffi }\end{array}$ & $\begin{array}{l}\text { dized } \\
\text { ents }\end{array}$ & $\begin{array}{c}\text { Standardized } \\
\text { Coefficients }\end{array}$ & \multirow[b]{2}{*}{$\mathrm{t}$} & \multirow[b]{2}{*}{ Sig. } \\
\hline & B & $\begin{array}{l}\text { Std. } \\
\text { Error }\end{array}$ & Beta & & \\
\hline 1 (Constant) & 12,691 & 0,993 & & 12,776 & 0,000 \\
\hline $\begin{array}{l}\text { Kepuasan } \\
\text { Masyarakat }\end{array}$ & 0,736 & 0,026 & 0,945 & 28,600 & 0,000 \\
\hline
\end{tabular}

Sumber : Data SPSS 27 
Berdasarkan table tersebut, diketahui (Sig.) sebesar 0,000 (lebih kecil) $<$ dari 0,05 sehingga dapat dikatakan terdapat pengaruh Kepuasan masyarakat (X) terhadap Wisata Danau Toba (Y). Dengan demikian pernyataan Ho diabaikan dan Hipotesis alternatif diterima.

$$
\text { Sedangkan jika melakukan }
$$

perbandingan nilai thitung dengan ttabel maka sesuai dasar kriteria uji t diketahui bahwa :

1. Jika thitung $>$ dari ttabel maka terdapat Pengaruh Kepuasan masyarakat terhadap Wisata Danau Toba.

2. Sebaliknya thitung $<$ dari ttabel maka tidak terdapat Pengaruh Kepuasan masyarakat (X)

Tabel. 7

ModelSummary

\begin{tabular}{lllll}
\hline \multicolumn{4}{c}{ ModelSummary } \\
\hline \multicolumn{4}{c}{ Adjusted } & $\begin{array}{l}\text { Std. Error } \\
\text { of the }\end{array}$ \\
Model & $\mathrm{R}$ & R Square & R Square & Estimate \\
\hline 1 & $.945^{\text {a }}$ & 0,893 & 0,892 & 1,212 \\
\hline a. Predictors: (Constant), Kepuasan Masyarakat \\
\hline
\end{tabular}

Sumber : Data SPSS 27 terhadap Wisata Danau Toba (Y).

Rumus mencari ttabel adalah sebagai berikut :

Nilai a/2 yaitu 0,025. Derajat kebebasan $(\mathrm{df})=\mathrm{n}-2$. Diketahui responden yang diteliti adalah 100 maka $\mathrm{df}=100-2=98$. Maka ttabel dalam distribusi t tabel di bawah ini dengan nilai 0,$025 ; 98$ adalah sebesar 1,98447 . Sedangkan besarnya pengaruh Kepuasan masyarakat $(\mathrm{X})$ terhadap Wisata Danau Toba (Y) dalam hasil regresi linear dapat dilihat pada output SPSS 27, bagian Model Summary dalam tabel berikut ini.
Dari output SPSS 27, diketahui Rsquarenya 0,893. Yang bermakna bahwa pengaruh Kepuasan Masyarakat (X) terhadap Wisata Danau Toba (Y) sebesar 89,3\%. Oleh karena itu $10,7 \%$ orang melakukan Wisata ke Danau Toba dipengaruhi faktor lainnya dan tidak diteliti dalam penelitian ini.

\section{Pembahasan}

\section{Komunikasi Pariwisata dalam Kualitas} Pelayanan Pariwisata terhadap kepuasan Wisatawan Kawasan Danau Toba

Berdasarkan tabel 1, yang telah memaparkan hasil jawaban responden maka dapat disimpulkan bahwa komunikasi pariwisata dalam kualitas pelayanan pariwisata terhadap kepuasan wisatawan kawasan Danau Toba sudah baik. Hal ini terlihat dari jawaban responden yaitu 3 sangat setuju dan 63 setuju bahwa kualitas pelayanan sudah sesuai Standar. Hanya 34 yang kurang setuju. Begitu pula dalam hal informasi yang telah digunakan di lokasi tersebut, 68 responden setuju mereka menggunakan komunikasi persuasive.

Dalam hal ini mereka juga mengakui kredibilitas pelayanan disana yakni 73 menjawab setuju. Hal ini terbukti dari 100 responden, 56 menjawab bahwa mereka sudah memperhatikan kepuasan pelanggan. Ada 86 dan 90 responden yang menjawab mengetahui informasi kenyamanan berwisata di Bukit Simarjarunjung melalui media massa dan media social sehingga tertarik berkunjung karena informasi tersebut. Responden juga menjawab bahwa mereka suka cara pelaku wisata berkomunikasi yaitu 75 orang dan masih menganggap positif pelayanan pelaku 
wisata Danau Toba yakni 68 orang. Walaupun mayoritas perempuan, yakni 58 orang (58\%). dan laki-laki hanya 42 orang, namun mereka sudah dianggap mewakili wisatawan yang menyukai pemandangan alam Wisata Danau Toba.

Komunikasi Pariwisata memang harus bersifat persuasive yakni membujuk dengan memberikan informasi dan balasan komunikasi yang memuaskan sehingga wisatawan merasa puas dan siap untuk datang kembali membeli produk dan jasa pelayanan wisata yang mereka berikan. Hal ini terbukti dari jawaban 85\% responden yang menjawab ada keinginan untuk kembali berkunjung ke kawasan wisata Danau Toba.

Komunikasi Pariwisata dalam Kualitas Produk Wisata terhadap kepuasan Wisatawan Danau Toba

Terkait kualitas produk wisata, 93 responden menjawab bahwa Atraksi Wisata Spot Foto menarik bagi mereka. Hal ini terbukti dari banyaknya produk kegiatan wisata yang ditampilkan di Bukit Simarjarunjung Danau Toba adalah spot foto. Spot foto berada di atas pohon. Spot foto seolah melayang di atas Danau dan lainnya. Produk spot foto merupakan komunikasi pariwisata yang unggul saat ini untuk menarik wisatawan menikmati liburan dan rasa nyaman serta bahagia jika mereka juga dapat merasakan moment seperti orang-orang yang sedang ada dalam foto yang diinformasikan di media massa dan media social.

Produk kegiatan wisata di Bukit Simarjarunjung Danau Toba lainnya adalah toko souvenir yang mudah ditemukan di lokasi wisata. Ada 62 responden menjawab setuju. Terdapat 99 responden, yang mengatakan setuju pemandangan alam Danau Toba Bukit Simarjarunjung memiliki Daya Tarik. Hal ini tidak jauh berbeda dengan yang mengatakan pemandangan Alam Hutan di Bukit Simarjarunjung menarik yaitu sebanyak 97 orang. Produk wisata pemandangan merupakan produk wisata yang selalu menjual untuk diinformasikan. Apalagi pemandangan hutan dan view Danau Toba sudah terkenal sampai ke ujung bumi dikarenakan keindahannya.

Komunikasi Pariwisata dalam Kualitas Daya Tarik Wisata terhadap kepuasan Wisatawan Kawasan Danau Toba

Komunikasi Pariwisata dalam hal kualitas daya tarik wisata mencakup banyak hal. Tidak hanya terkait pelayanan pelaku wisata dan produk wisata. Tetapi juga berkaitan dengan Akses menuju lokasi yang mudah dilalui. Responden yang menjawab setuju ada 75 orang. Selain itu, terdapat keinginan berwisata karena akses wisata mudah dijawab setuju oleh 81 responden.

Informasi kenyamanan menikmati wisata juga menjadi kualitas daya tarik bagi wisatawan untuk berkunjung. Hal ini dijawab setuju oleh 86 responden. Hal ini semakin cepat diketahui oleh banyak wisatawan adalah dari informasi di media massa yang mempengaruhi daya tarik untuk berkunjung. Ada 90 responden yang menjawab. Berdasarkan hal ini dapat disimpulkan bahwa komunikasi pariwisata berkaitan erat dengan kualitas komunikasi, penataan lokasi wisata, sikap pelaku wisata yang dipercaya yang mampu berkomunikasi secara persuasive dan kemampuan mengelola informasi di media social dan media massa yang dapat mempengaruhi keinginan wisatawan untuk berkunjung dan juga produk wisata yang mereka ingin dapatkan harus dikelola lebih baik.

Namun dalam hal kualitas daya tarik, masih banyak juga wisatawan yang mengeluhkan masalah fasilitas umum dan kebersihan yang belum dikelola dengan baik. Hal ini diketahui dari jawaban responden yang mengatakan tidak setuju bahwa Fasilitas Umum Bersih dan Nyaman yaitu 71 orang kurang setuju dan 4 orang tidak setuju. Selain itu terdapat juga 64 responden yang kurang setuju Fasilitas Toilet, Parkir, dan tempat ibadah memuaskan. Ada 6 orang bahkan tidak setuju.

Hal ini harus segera diperbaiki agar ke depannya kondisi kualitas pariwisata Danau Toba dapat bersaing dengan pariwisata dunia.

Kepuasan Masyarakat Dalam Komunikasi Pariwisata Berpengaruh Terhadap Wisata Danau Toba 
Berdasarkan pengujian regresi linear sederhana, $\mathrm{a}=$ angka konstan dari unstandardized coefficients yaitu sebesar 12,691 yang berarti jika kepuasan masyarakat tidak ada maka nilai konsisten Wisata Danau Toba (Y) sebesar 12,691. Sedangkan keterangan b dalam tabel tersebut merupakan angka koefisien regresi yaitu sebesar 0,736. Hal ini berarti setiap penambahan $1 \%$ tingkat kepuasan masyarakat $(\mathrm{X})$ akan meningkatkan wisata Danau Toba sebesar $+0,736$. Jika dimasukkan ke dalam rumus persamaan regresi, akan terlihat sebagai berikut : $\mathbf{Y}=\mathbf{1 2 , 6 9 1 + 0 , 7 3 6 X}$. Artinya Wisata danau toba akan meningkat menjadi 12,691+0,736 jika variabel kepuasan masyarakat meningkat satu \%.

Berdasarkan pengujian regresi juga dapat dilihat bahwa nilai thitung sebesar 28,600 > dari ttabel sebesar 1,98447 yang berarti bahwa Hipotesisnul ditolak dan Hipotesis alternatif diterima. Hal ini berarti Kepuasan masyarakat (X) berpengaruh terhadap Wisata Danau Toba (Y). Seberapa banyak pengaruhnya dapat dilihat dari output SPSS diatas, dimana nilai RSquare sebesar 0,893. Artinya bahwa pengaruh Kepuasan Masyarakat (X) terhadap Wisata Danau Toba (Y) adalah sebesar 89,3 \% sedangkan 10,7 \% Wisata Danau Toba dipengaruhi oleh variabel lainnya yang tidak ada dalam penelitian ini.

\section{CONCLUSIONS}

1. Komunikasi Pariwisata dalam Kualitas Pelayanan Pariwisata terhadap kepuasan wisatawan Kawasan Danau Toba sudah tergolong memuaskan sesuai jawaban responden yang menjawab kualitas pelayanan sesuai standar dengan informasi yang disampaikan sudah menggunakan komunikasi persuasive yaitu 3 sangat setuju dan 63 setuju bahwa kualitas pelayanan sudah sesuai Standar. Dan 68 responden setuju mereka menggunakan komunikasi persuasive.
2. Komunikasi Pariwisata dalam Kualitas Produk Wisata kepuasan Wisatawan Danau Toba melalui atraksi foto sangat menarik karena $93 \%$ responden memberikan apresiasi positif terkait wisata buatan yang digabungkan dengan latar pemandangan alam Danau Toba melalui spot Foto yang ada di Bukit Indah Simarjarunjung.

3. Analisis Komunikasi Pariwisata dalam Kualitas Daya Tarik Wisata terhadap kepuasan wisatawan Kawasan Danau Toba menunjukkan pengaruh yang signifikan. Berdasarkan uji instrument dan uji regresi linear sederhana yang sudah dipaparkan di halaman terdahulu maka Kepuasan Masyarakat yaitu wisatawan Danau Toba berpengaruh positif terhadap Wisata di Danau Toba. Berdasarkan rumus persamaan regresi, dapat disimpulkan bahwa $\mathbf{Y}=$ 12,691+0,736X memiliki arti bahwa Wisata danau toba akan meningkat menjadi 12,691+0,736 jika variabel kepuasan masyarakat meningkat satu \%. Kemudian thitung 28,600 $>$ dari ttabel yakni 1,98447 menjelaskan bahwa $\mathrm{H}$ nul ditolak dan $\mathrm{H}$ alternatif diterima. Sedangkan pengaruhnya diketahui dari nilai R Square sebesar 0,893. Artinya bahwa pengaruh Kepuasan Masyarakat (X) terhadap Wisata Danau Toba (Y) adalah sebesar 89,3\% sedangkan 10,7\% Wisata Danau Toba dipengaruhi faktor lainnya. 


\section{REFERENCES}

Baharuddin, A., Kasmita, M., \& Salam, $R$. (2017). Analisis Kepuasan Wisatawan Terhadap Daya Tarik Wisata Malioboro Kota Yogyakarta. Jurnal Ad'ministrare, 3(2),

107. https://doi.org/10.26858/ja.v3i2.2571

Ghozali, I. (2011). Aplikasi Analisis Multivariate Dengan Program SPSS (Edisi Keen). Badan Penerbit Universitas Diponegoro.

Hasan, A. (2015). Tourism Marketing. CAPS.

Kotler, P. D. K. L. K. (2007). Manajemen Pemasaran. Edisi Ketiga Belas (13th ed.). Erlangga.

Kusumaningrum, D. (2009). Persepsi Wisatawan Nusantara Terhadap Daya Tarik Wisata. Kajian.

Rao, P. (2006). Measuring Customer Perception Through Factor Analysis. The Asian Manager.

Sugiyono, $V . \quad W$. (2014). Metode Penelitian lengkap Praktis dan Mudah Dipahami. Pustaka Baru Press.

Sujarweni. (2014). Metode Penelitian: Lengkap, Praktis, dan Mudah Dipahami. Pustaka Baru Press.

Sumut, BPS. (2019). Perkembangan Pariwisata dan Transportasi. 03, 1-10. https://padanglawaskab.bps.go.id/pressre lease/2019/01/03/55/jumlah-wisatawanmancanegara-sumatera-utara-november2018-sebesar-13-571-kunjungan.html 